\title{
DEFINIRANJE I UPORABA NAZIVLJA ZA E-IZVEDBU NASTAVE
}

\author{
Jadranka Nemeth-Jajić, Tonća Jukić
}

Filozofski fakultet Sveučilišta u Splitu, Hrvatska

jadranka@ffst.hr; tjukic@ffst.hr

Primljeno: 16. 11. 2020.

\begin{abstract}
Nastava koja se zbog pandemije uzrokovane koronavirusom $u$ hrvatskim školama i na hrvatskim sveučilištima u drugom polugodištu školske odnosno u ljetnom semestru akademske godine 2019./2020. odvijala na mreži u javni i stručni diskurs unijela je različite, katkada istoznačne, katkada bliskoznačne, katkada nedovoljno precizne nazive, što dovodi do potrebe preispitivanja njihova značenja i opsega pojma na koji se oni odnose. Kako bi se pridonijelo preciznijoj uporabi nazivlja za e-izvedbu nastave, $u$ ovome radu pozornost je stoga ponajprije posvećena definiranju sedam izabranih naziva, a potom su postupkom pretraživanja mrežnih stranica na hrvatskome jeziku po ključnim riječima izdvojeni primjeri njihove uporabe. Posrijedi su nazivi e-učenje, e-poučavanje, e-nastava, mrežna nastava, online nastava, virtualna nastava i nastava na daljinu.
\end{abstract}

Ključne riječi: e-učenje, e-poučavanje, e-nastava, mrežna nastava, online nastava, virtualna nastava, nastava na daljinu

\section{Nacrtak}

Nastava koja se zbog pandemije uzrokovane koronavirusom u hrvatskim školama i na hrvatskim sveučilištima u drugom polugodištu školske odnosno u ljetnom semestru akademske godine 2019./2020. odvijala na mreži u javni i stručni diskurs unijela je mnoge, do nedavno rubno korištene nazive. »Nastava na daljinu, e-nastava, virtualna nastava, online učenje ...«, navodi tako jedna od sudionica mrežne komunikacije koja se vodi među odgojno-obrazovnim djelatnicima, »tek su neki od izraza koje smo često mogli čuti u posljednje vrijeme - 'novo 
normalno vrijeme' koje nas je sve snašlo početkom ove godine« (Krtanjek, 2020). Učestalost uporabe, s jedne strane, a s druge strane razlike među autorima u definiranju takvih naziva upućuju na potrebu preispitivanja njihova značenja i opsega pojma na koji se oni odnose.

Od nazivlja za e-izvedbu nastave izabrano je sedam naziva: $e$-učenje, e-poučavanje, e-nastava, mrežna nastava, online nastava, virtualna nastava i nastava na daljinu, s trima ishodišnim pojmovima: učenje, poučavanje i nastava. U prvome dijelu rada razmotreno je kako se navedeni ishodišni pojmovi određuju u pedagogijskoj znanosti. U drugome, središnjem dijelu rada, pregledom i analizom literature na hrvatskome i engleskome jeziku u kojoj se razmatrani nazivi definiraju, utvrđuje se njihovo značenje i opseg pojma s posebnim obzirom na značenjske odnose istoznačnosti i bliskoznačnosti. Pritom se, kad je to potrebno, uzgredno komentiraju i neki drugi njima bliski nazivi. Primjeri uporabe razmatranih naziva, koji su izdvojeni postupkom pretraživanja mrežnih stranica na hrvatskome jeziku po ključnim riječima, doneseni su u trećem dijelu rada.

\section{Učenje, poučavanje, nastava}

$\mathrm{U}$ pedagogijskim se disciplinama pojam učenje određuje kao »ped. ${ }^{1}$ djelatan oblik stjecanja znanja i umijeća te njihova zadržavanja i reproduciranja na svim područjima psihofizičkog života« (Rječnik hrvatskoga jezika, 2000). Također je bitno djelovanje učenja na pojedinca te je učenje »trajna i relativna specifična promjena individue ugrađena u njeno ponašanje, nastala pod utjecajem prethodne aktivnosti« (Peko, Pintarić, 1999, 20) ili »relativno trajno mijenjanje ponašanja do kojega dolazi pod utjecajem stečenog iskustva« (Matijević, Radovanović, 2011, 392). Određujući učenje kao »proširenje kompetencije razmišljanja i djelovanja koje se ostvaruje samoorganiziranom obradom vanjskih poticaja i unutarnjih impulsa«, Meyer ističe kako nijedan čovjek ne može učiti za drugoga, već učiti može svatko samo za sebe $(2002,52)$. Učiti se može, navodi isti autor, s učiteljem, protiv učitelja i bez učitelja jer je riječ o autopojetskom (samodjelatnom) procesu (Meyer, 2002, 51). Učenje je cjeloživotan proces koji se ostvaruje u

${ }^{1}$ Kratica od 'u pedagogiji, pedagoški'. 
vidu formalnoga, neformalnoga i informalnog učenja, a oni se razlikuju u stukturiranosti, certificiranosti i namjeri. Formalno i neformalno učenje strukturirano je u smislu ciljeva učenja, vremena i podrške učenju, a s motrišta onoga koji uči sadrži namjeru. Informalno učenje nije strukturirano i uglavnom ne sadrži namjeru. Formalno se učenje odvija u odgojno-obrazovnim ustanovama, a završava izdavanjem službenog dokumenta (svjedodžbe, diplome) o stjecanju određenoga stupnja obrazovanja, dok se neformalno i informalno učenje, za koje se u pravilu ne izdaje javna isprava, odvija u životnoj svakodnevici - na poslu, u obitelji i u slobodnom vremenu (usp. Communication from the Commission: Making a European Area of Lifelong Learning a Reality (COM, 2001, $32,35)$ ). Giesecke pak shvaća učenje kao pojam nadređen svim pedagoškim nastojanjima te promatra čovjeka kao »biće koje tek u učenju postaje čovjekom « $(1993,41)$.

Poučavanje ${ }^{2}$ je, za razliku od učenja, usmjereno na drugoga, ono je, prema transmisijskome pristupu, prenošenje vlastitog znanja i vještina na drugoga (Težak, 1996, 8), a prema transakcijskome pristupu »vođenje subjekta do sposobnosti stvaranja spoznaja i informacija koje će mu omogućiti uspješniji rad i ispunjeniji život« (Peko, Pintarić, 1999, 20), to jest ono, prema kompetencijskome pristupu, »označuje učiteljevo organiziranje aktivnosti učeniku, gdje učenik radeći te aktivnosti na određenome nastavnom sadržaju postiže postavljene ishode učenja« (Matijević, Topolovčan, 2017, 203). U skladu s tim suvremeni nastavnik »nije više ekskluzivni nositelj i prenositelj nastavnog sadržaja (...), već bi trebao razvijati kod učenika sposobnost stvaralačkog učenja« (Radeka, 2007, 285). Iz toga proizlaze i nove uloge nastavnika - poticatelja, odgojitelja, medijatora i socijalnog integratora, mentora i organizatora (usp. Previšić, 2003), koji primjenjuje nove tehnologije u nastavi i prilagođuje nastavu »izazovima suvremenoga društva utemeljenog na znanju i cjeloživotnom učenju« (Hirni, 1996, prema Peko, 2007, 267). Pri određivanju poučavanja u obzir se uzima i institucionalni kontekst te je poučavanje »s nastavnim programom usklađe-

${ }^{2} \mathrm{U}$ hrvatskoj je tradiciji uvriježen naziv poučavanje, a rabe ga i mnogi suvremeni autori, primjerice Peko i Pintarić (1999), Bežen (2008), Visinko (2010), Matijević et al. (2016) i dr. Podučavanje se, kako navodi Težak, najčešće odnosi na individualnu instrukciju $(1996,8)$. 
no 'prikazivanje' određenog predmetnog, smisaonog ili problemskog sklopa (...) u pedagoški oblikovanom okruženju za učenje« (Meyer, 2002, 52) odnosno »didaktička pomoć nastavnika (učitelja) učeniku u učenju« (Matijević et al., 2016, 449). »Učenje i poučavanje«, ističe Meyer, »međusobno su dijalektički povezani« $(2002,52)$, a učitelji već od početka školovanja »nastoje postupno osposobiti učenike za samostalno učenje kako bi nakon školovanja bivši učenici mogli nastaviti samostalno učiti« (Matijević et al., 2016, 449). Iz navedenih definicija razvidno je da se učenje određuje s motrišta učenika, a poučavanje $s$ motrišta učitelja/nastavnika.

U pojmu nastave, a riječ nastava u hrvatsko školsko nazivlje ulazi u 19. stoljeću pod utjecajem ruskog jezika (usp. Težak, 1996, 9), stječu se pak i učenje i poučavanje. Nastava se temelji i na učenju i na poučavanju, reći će Peko i Pintarić $(1999,20)$, ona označuje »svrhoviti, dvosmjerni, planski i racionalno organizirani radni proces učenja i poučavanja«, navodi Milat $(2005,49)$, a učenje i poučavanje kao glavne aktivnosti u nastavnome procesu također ističu Matijević, Bilić i Opić (2016, 345). Kao i kod poučavanja, i pri određivanju pojma nastave bitan je institucionalni kontekst: »Nastava je bez premca najvažniji oblik institucionaliziranog poučavanja i učenja«, podsjeća Meyer, te se može odrediti kao "planska interakcija nastavnika i učenika za izgradnju predmetne, socijalne i osobne kompetencije u institucionalnom okviru škole ili školi sličnih ustanova« (2002, 35-36). Glavni su čimbenici nastave nastavnik (učitelj), učenik i nastavni sadržaji (program), što čini didaktički trokut (Matijević, Topolovčan, 2017, 199). Nastava je također organizirana djelatnost, »organizirani proces učenja i poučavanja $u$ školi, to jest organizirani zajednički rad nastavnika (učitelja) i učenika« (Matijević, Radovanović, 2011, 392). ${ }^{3}$ Pojedini autori potrebnim drže istaknuti komunikacijsku značajku nastave. Peko i Pintarić tako navode da je nastava "pedagoški osmišljena i sustavno organizirana komunikacija« (1999, 23), dok Bratanić u komunikaciji vidi osnovu »za sve međusobne odnose, pa tako i za odnose u odgoju i nastavi, u obitelji i školi« $(2002,73)$. »Cjelokupna odgojna djelatnost počiva na komunikaciji«, ustvrđuje Bratanić te ističe kako je komunikacija »ključ

3 Organiziranost kao značajku nastave navode mnogi autori, npr. Težak (1996, 9), Jelavić (1998, 20), Antić (1999, 649), Matijević i Topolovčan $(2017,136)$ i dr. 
odgoja, temelj uspješne nastave i svih međusobnih odnosa« $(2002,73)$. Uz nastavu se dakle povezuju i odgoj i obrazovanje, bilo da se oni promatraju kao cilj nastave (usp. Jelavić, 1998, 20; Peko, Pintarić, 1999, 23; Matijević et al., 2016, 445), bilo da ulaze u temeljnu definiciju:

»(...) nastava je jedinstveni odgojno-obrazovni proces, to jest intencionalno i sustavno učenje (znanja, vještina, sposobnosti i druge osobine ličnosti - vrijednosti, stavovi, interesi, motivi, navike, slika o sebi, odgovornost) usmjereno na porast ljudskih mogućnosti pojedinca, utemeljen na njegovoj personalizaciji.«(Jelavić, 1991, 21)

Stoga bez odgoja, zaključuje isti autor, nema nastave (Jelavić 1991, 21). Neodvojivost i međuovisnost odgoja i obrazovanja ističu i drugi autori. »Ne može se poučavati, a da se istodobno i ne odgaja«, navodi Meyer (2002, 39), a Bratanić napominje kako je riječ o "podsustavima jednog cjelovitog sustava koji se mogu misaono zasebno analizirati radi boljeg upoznavanja, ali nikada gubeći iz vida njihovu cjelovitost, međusobnu uvjetovanost i jedinstvenost« $(2002,39)$.

\section{Definiranje razmatranih naziva}

\subsection{E-učenje, e-poučavanje, e-nastava}

Predmetak $e$ ispred riječi odvojen spojnicom kratica je odnosnoga pridjeva elektronički pa se pojmovi pred kojima se taj predmetak javlja definiraju u odnosu na suvremenu informacijsku i komunikacijsku tehnologiju (IKT). Zadržavajući značenje ishodišnih riječi, nazivi elektroničko učenje, elektroničko poučavanje, elektronička nastava pokazuju se usklađenima sa semiotičkim načelima oblikovanja nazivlja: prozirni su, to jest lako razumljivi i bez posebna tumačenja, prikladni su i sustavni jer su posrijedi općeprihvaćeni neutralni nazivi usidreni u pojmovni sustav, sažeti su i usklađeni s jezičnim sustavom hrvatskoga jezika (usp. Hrvatski terminološki portal, 2020).

Zamijećeno je međutim da se u nekim definicijama e-učenja pod tim pojmom razumijeva i poučavanje. Tako se u priručniku E-učitelj - suvremena nastava uz pomoć tehnologije navodi ova opća definicija e-učenja: »U najširem smislu e-učenje je bilo koji oblik učenja i poučavanja koji se izvodi uz pomoć informacijskih i komunikacijskih tehnologija« (Jandrić et al., 2016, 6). Također, u Strategiji e-učenja Sveu- 
čilišta u Zagrebu e-učenje se određuje kao »proces obrazovanja (proces učenja i podučavanja) uz uporabu informacijske i komunikacijske tehnologije, koja doprinosi unapređenju kvalitete toga procesa i kvalitete ishoda obrazovanja« $(2007,5)$. I definicijom Tonyja Batesa, jednoga od vodećih istraživača na području e-učenja, u pojmu e-učenja obuhvaćeno je i poučavanje. E-učenje njome se određuje kao »sve aktivnosti temeljene na uporabi računala i interneta koje podržavaju poučavanje i učenje i u učionici i na daljinu« (Bates, 2008). ${ }^{4}$

U navedenim se definicijama učenje i po(d)učavanje ili izrijekom navode ili su obuhvaćeni pojmom obrazovanja. Iz toga slijedi da se e-učenje upotrebljava kao pojam nadređen pojmu e-poučavanje, što upućuje na to da je pojam e-učenje proširio svoj opseg. Potvrđuje to i broj definicija pronađenih na mreži pretraživanjem po ključnim riječima, gdje se ponajprije definira e-učenje (u koje se uključuje i poučavanje), dok se e-poučavanje s pridruženom sastavnicom (predmetak $e$ ), koja ga određuje, uglavnom ne definira, a rabi se u osnovnom značenju ishodišne riječi (poučavati drugoga). Takvo proširivanje opsega pojma e-učenje može biti posljedica prevođenja s engleskoga, jezika u kojem e-learning često podrazumijeva i učenje i poučavanje (usp. prethodno navedenu Batesovu definiciju). Uzme li se međutim u obzir tehnologija, razvidno je da su e-poučavatelj i e-učenik različito usmjereni pri njezinoj uporabi: prvi na iskorištavanje mogućnosti elektroničkih medija i njihove programske podrške u pripremi i provedbi svrhovita, metodički osmišljena poučavanja; drugi na sadržaje učenja. Stoga bi u pedagogijskoj znanosti uspostavljenu razliku između učenja i poučavanja trebalo zadržati i kada je riječ o e-učenju i e-poučavanju. U tom smislu najprihvatljivijom držimo definiciju e-učenja koja glasi: »razni oblici učenja koje je omogućeno ili obogaćeno elektroničkim medijima, najčešće multimedijem, internetom, mobilnim telefonima, elektroničkom poštom itd.« (Matijević, Radovanović, 2011, 376) odnosno »formalno, neformalno i informalno učenje koje je potpomognuto elektroničkim medijima i e-komunikacijom; elektroničko učenje« (Matijević, Topolovčan, 2017, 191). Sukladno tomu i e-poučavanje moglo

${ }^{4}$ Prijevod autorica članka. Definicija u izvorniku glasi: » (...) all computer and Internet-based activities that support teaching and learning - both on-campus and at a distance« (Bates, 2008). 
bi se odrediti kao poučavanje koje je omogućeno ili obogaćeno elektroničkim medijima, to jest kao poučavanje potpomognuto elektroničkim medijima i e-komunikacijom.

Vrijednim držimo svratiti pozornost i na razliku među pojmovima e-učenje i 'online učenje', koja upućuje na to da su posrijedi bliskoznačni, a ne istoznačni nazivi. Na Carnetovim mrežnim stranicama naime pojašnjava se kako je e-učenje širi pojam od 'online učenja', koje određuje uporaba interneta (ili, op. a., bilo koje druge računalne mreže), dok se u e-učenju osim interneta mogu upotrebljavati i nastavni materijali s nosača digitalnih informacija poput DVD i CD medija (Što je online učenje?, CARNET; usp. i Pop, 2020). Za englesku riječ online, koja se u Informatičkome enciklopedijskom rječniku definira kao ono što je priključeno na internet ili neku sličnu računalnu mrežu (Panian, 2005, 72), normativno je preporučena istovrijednica mrežni (usp. Hrvatski pravopis, 2013; Bolje je hrvatski), a u skladu s tim i dvorječni naziv mrežno učenje. Kako riječ online ima status strane riječi jer nije uklopljena u hrvatski jezični sustav, tada se kao i druge strane riječi, nađe li se u hrvatskome tekstu, treba pisati kosim slovima (kurzivom).

Mogućnosti koje pruža uporaba prijenosnih računala, Mp3 playera, a osobito mobitela i tableta, unijele su i pojam mobilnog ili m-učenja, dostupnoga bilo kada i bilo gdje, pa se ono određuje kao »učenje na više mjesta uporabom različitih osobnih elektroničkih uređaja« (Matijević, Topolovčan, 2017, 138), pri čem je bitna mobilnost subjekta koji uči i interakcija koja se ostvaruje prijenosnim medijima. M-učenje može se dakle promatrati kao inačica e-učenja (Bozkurt, 2019).

Definicije e-učenja koje se mogu pronaći na mreži katkada nisu dovoljno precizne, na što također valja upozoriti. Dostajat će dva primjera. Pretraživanjem te ključne riječi prva se otvara definicija na $\mathrm{Wi}$ kipediji, pri čem je posrijedi prijevod s engleskoga jezika u kojem se riječ 'naobrazba' ne rabi u točnom značenju: »Elektroničko učenje ili e-učenje (engl. e-learning), uporaba elektroničkih medija, edukacijske tehnologije te informacijskih i komunikacijskih tehnologija (ICT) ${ }^{5} \mathrm{u}$ naobrazbi«. Naobrazba je naime rezultat izobrazbe, koja se odnosi na »stjecanje dopunske i specijalne naobrazbe: izobrazba kadrova, izobrazba liječnika, svećenika, trgovaca, obrtnika itd.« (Težak, 1996, 8),

5 Pravopisna norma prednost daje hrvatskoj pokrati (ICT > IKT). 
ili obrazovanja, koje označuje proces (Težak, 1996, 8). Drugi primjer pokazuje kako preuzimanje engleskih izvora može izazvati nedoumice. Tako se na mrežnim stranicama Centra za e-učenje pri Sveučilišnom računskom centru navodi da predmetak $e$ »ponajmanje predstavlja elektroničko učenje « što se oprimjeruje engleskim nazivima i hrvatskim prevedenicama Experience Learning (iskustveno učenje), Everywhere Learning (učenje 'posvuda'), Enhanced Learning (povećano, bolje učenje), Extended Learning (prošireno učenje) (E-učenje, SRCE). No to ne vrijedi za hrvatski jezik u kojem se predmetak $e$ rabi upravo u značenju elektronički.

$\mathrm{Za}$ pojam e-nastave također je bitno značenje ishodišne riječi. Kao što proizlazi iz određenja nastave navedenih u prethodnome potpoglavlju, nastava je oblik institucionaliziranog poučavanja i učenja, jedinstveni odgojno-obrazovni proces, nastava je i komunikacija kojoj je cilj odgoj i obrazovanje. Sve bi to trebalo vrijediti i za elektronički posredovanu nastavu ili e-nastavu. Može li se međutim za e-nastavu jednostavno reći da ona obuhvaća e-učenje i e-poučavanje, ${ }^{6}$ e-odgoj i e-obrazovanje ili e-komunikaciju kojoj je cilj odgoj i obrazovanje?

Promotrimo prvi par, e-učenje i e-poučavanje. Prema klasifikaciji oblika e-učenja, koja se nalazi na mrežnim stranicama Centra za e-učenje, prvi je oblik e-učenja povezan s primjenom informacijsko-komunikacijske tehnologije u klasičnoj nastavi u učionici, pa se za takvo e-učenje (i e-poučavanje, op. a.) ne bi moglo reći da je ono e-nasta$v a$, nego je to, kao što se i navodi, klasična nastava u učionici, a koja je potpomognuta informacijsko-komunikacijskom tehnologijom (npr. uporaba računalne prezentacije ili videozapisa posredovanih računalom i dr.) (usp. E-učenje, SRCE). E-nastava zapravo bi se odnosila na hibridnu ili mješovitu nastavu, koja i jest kombinacija klasične nastave u učionici i elektroničke nastave (npr. postavljanje nastavnoga materijala u repozitorij, otvaranje rasprava na forumu, mogućnost savjetovanja s nastavnikom uporabom e-pošte i dr.). U mješovitu nastavu može se uvrstiti i najnoviji oblik istodobnog odvijanja nastave u učionici i elektroničke nastave, koji se u nas u nekim školama i na fakultetima upravo uvodi, a to je da se jedan dio sudionika (učenika, studenata) nalazi u

6 Tako se primjerice e-nastava izjednačuje s e-učenjem i e-poučavanjem, usp.: »eNastava (eLearning + eTeaching)« (Pogarčić et al., 2007, 2). 
učionici, a drugi dio nije fizički prisutan, nego se preko aplikacija poput Zooma, Meeta i drugih mrežno povezuje sa stvarnom učionicom, pri čem tehnološka podrška omogućuje ne samo praćenje nastave nego i sudjelovanje u nastavi. E-nastava također se odnosi na 'mrežnu (online) nastavu' kad se nastavni predmet/predmeti u potpunosti izvode na mreži. Prema tome e-učenje i e-poučavanje mogu se, ali ne moraju primjenjivati u klasičnoj nastavi u učionici, a značajka su mješovite i mrežne nastave (usp. Pop, 2020).

Nadalje, u malobrojnim definicijama e-nastave, primjerice »e-nastava je oblik obrazovanja podržan računalima i internetom « (Pogarčić et al., 2007, 2), uglavnom se ispušta odgoj, a držimo da to nije slučajno. Tehnološka sastavnica e-nastave doima se prikladnijom za razvoj kognitivne negoli konativne sfere čovjekove osobnosti. Međutim, već je u pojmu učenja, a bez učenja i poučavanja nema nastave, pretpostavljeno djelovanje na sva područja psihofizičkog života; učenjem se šire spoznaje, ali se izgrađuju i stavovi i vrijednosti. I nastavnici se, pripremajući se za nastavu uopće, pa tako i za e-nastavu, među ostalim didaktičkim načelima vode i načelom odgojnosti, stoga odgoj ne bi trebalo olako isključivati ni iz definicija e-nastave. E-nastavu bilo bi posve moguće odrediti primjerice kao odgojno-obrazovni proces koji se odvija uporabom elektroničkih medija i informacijsko-komunikacijske tehnologije. Glede naziva e-odgoj i e-obrazovanje zanimljivo je primijetiti da je na mreži ipak nađena iako samo jedna pojavnica e-odgoj (na službenim mrežnim stranicama Grada Zagreba) za razliku od e-obrazovanja koje ima široku uporabu. E-obrazovanje određuje se pak kao »formalno i neformalno obrazovanje koje se oslanja na raznovrsne oblike uporabe informacijsko-komunikacijskih tehnologija« (Matijević, Topolovčan, 2017, 191), a kako je nastava institucionalizirana djelatnost, odatle slijedi da je e-nastava oblik formalnoga obrazovanja. Dodatno, kao što je obrazovanje širi pojam od nastave, tako je i e-obrazovanje širi pojam od e-nastave. E-obrazovanje, kako navode Jandrić i Boras, "predstavlja obrazovanje uronjeno u habitus umreženoga društva« $(2012,135)$.

I naposljetku, može li se za e-nastavu reći da ona obuhvaća e-komunikaciju kojoj je cilj odgoj i obrazovanje? Držimo da može. U mješovitoj i mrežnoj nastavi uspostavlja se elektronička komunikacija između svih čimbenika didaktičkoga trokuta - nastavnika, učenika i nastavnih sadržaja. Štoviše, nastavnici i učenici uspostavljaju komuni- 
kaciju i s tehnikom i tehnologijom, koja u e-nastavi tako postaje njezinim četvrtim čimbenikom koji s prethodnim trima čini didaktički četverokut (usp. Matijević, Topolovčan, 2017, 199). Didaktički četverokut ujedno je razlikovno obilježje e-nastave.

\subsection{Mrežna nastava, online nastava, virtualna nastava}

Odrednice uz riječ nastava preciziraju značenje naziva istaknutih u podnaslovu. 'Online nastava' i njezin hrvatski parnjak, a time i preporučen naziv mrežna nastava, kao i nazivi 'online učenje' i mrežno učenje, istoznačnice su, a označuju nastavu koja se izvodi na mreži ili posredstvom mreže. Je li naziv mrežna nastava istoznačan i s nazivom virtualna nastava?

Pridjev virtualan, koji potječe iz latinskoga, u Rječniku hrvatskoga jezika definira se »koji postoji kao mogućnost; potencijalan, možebitan, moguć« (2000), a u mrežnom izdanju Hrvatske enciklopedije stoji: »1. Koji ne postoji u stvarnosti; nestvaran, izmišljen, prividan (virtualan svijet, virtualan rat). 2. Koji je nastao, koji djeluje uz pomoć računala; računalan, internetski (virtualna knjižnica).« Upravo drugo značenje, jer ističe ulogu računala, odgovara pojmu virtualne nastave, no ipak se, iako je ona za svoje sudionike, kao što je poznato, nedavno bila itekako stvarna, ne gubi veza ni s prvim značenjem, dijelom stoga što se ta nastava odvija u prividnom (virtualnom ${ }^{7}$ prostoru koji je stvorila računalna tehnologija i »koji postoji samo u svijetu umreženih računala« (Bežen, 2008, 282). U skladu s navedenim virtualna se nastava može odrediti kao nastava koja se izvodi uz pomoć računala preko računalne mreže u prividnom prostoru umreženih računala. Iz toga bi proizlazilo da su virtualna nastava i mrežna nastava istoznačni nazivi. Međutim, ima li se na umu da virtualna nastava u svojem značenju uključuje i (prividan) prostor, koji je njezino razlikovno obilježje, ti nazivi ipak nisu potpuno istoznačni, nego su bliskoznačni, što potvrđuje i antonimni par virtualna nastava - stvarna nastava (mrežna nastava i stvarna nastava nisu u odnosu antonimije). Naziv virtualna nastava tako

7 Za prividan prostor u uporabi je i riječ kiberprostor (engl. cyberspace) koji »označuje prostor svjetski umreženih računala« $\mathrm{i}$ »omogućuje razmjenu informacija između svih umreženih ustanova i pojedinaca« (Bežen, 2008, 282; usp. Kiš, 2000, 258). 
upućuje na to da se nastava ne odvija u stvarnome, nego u prividnome prostoru.

Riječi virtualan i 'online' u hrvatskome standardnom jeziku imaju pak različit status: prva je posuđenica iz latinskoga jezika, prilagođena jezičnom sustavu hrvatskoga jezika, a druga je strana, engleska riječ, neuklopljena u hrvatski jezični sustav. »Nazivi latinskoga i grčkoga podrijetla«, prema terminološkim načelima, »imaju prednost pred nazivima preuzetim iz engleskoga, njemačkoga, francuskoga itd." (Hudeček, Mihaljević 2009, 70) zbog toga što su civilizacijski i kulturološki razlozi pridonijeli tomu da su europski jezici, pa tako i hrvatski, razvili odgovarajuće mehanizme da mogu grčko-latinske elemente primati na prikladan način (Hudeček, Mihaljević 2009, 59). Naziv virtualna nastava prema tome usklađen je s terminološkim načelima te je prikladan za uporabu i u znanstvenome funkcionalnom stilu. No valja imati na umu da »(...) ni riječ stranoga podrijetla (ni usvojenica, ni prilagođenica, ni tuđica, ni strana riječ u užem smislu), nije nepotrebna u svim svojim značenjima i u svim mogućim oblicima uporabe « (Pranjković, $2010,42)$, pa se tako i naziv 'online nastava', kao i 'online učenje', svojstven žargonu i razgovornomu stilu, može, kada to zatreba, nalaziti i u drugim funkcionalnim stilovima.

Zanimljivo je promotriti još neke odrednice kojima se nastava u stvarnoj učionici nastoji razlikovati od mrežne nastave. Kaže se da je nastava u učionici nastava 'uživo' ili se rabi prevedenica engleskoga izraza face to face pa se takva nastava opisuje kao nastava 'licem u lice'. Međutim, sve naprednije tehnološke mogućnosti na kojima se zasniva mrežna nastava razlikovnost navedenih odrednica dovode u pitanje: uključenjem kamere mrežna nastava postaje nastava licem u lice, a njezinim odvijanjem u stvarnom vremenu (sinkrona nastava) postaje i nastavom uživo.

\subsection{Nastava na daljinu}

Engleski nazivi distance teaching i distance education na hrvatski se jezik najčešće prevode nazivima nastava na daljinu i obrazovanje na daljinu, pri čem je za određivanje njihovih značajka nezaobilazna udaljenost subjekata nastave (King et al., 2001, 10; Saykili, 2018, 5; Bozkurt, 2019, 272): 
»Bitna obilježja onoga što nazivamo nastavom na daljinu i obrazovanjem na daljinu proizlaze iz činjenice da se poučavatelji i subjekti koji uče ne susreću svakodnevno na nekome dogovorenome mjestu, odnosno da su prostorno i vremenski udaljeni.« (Matijević, Topolovčan, 2017, 137)

Nastava na daljinu u svojoj se povijesti provodila (a i dalje se može provoditi) posredstvom medija koji omogućuju udaljenu komunikaciju, kao što su pisma, telefon, radio, televizija, no od početka 21. stoljeća, navodi Matijević, »nastava na daljinu podrazumijeva izvođenje obrazovnog programa oslanjanjem na internetske veze (web-tehnologiju, e-poštu te različite nosače multimedijskog softwera, npr. DVD, USB, Mp3 i sl.)« (Matijević, Topolovčan, 2017, 138) te se danas definira i kao »oblik učenja i poučavanja u kojemu se ne ostvaruje fizička prisutnost učenika i učitelja, već se proces učenja i poučavanja odvija $\mathrm{u}$ virtualnom okruženju uz podršku digitalnih tehnologija (Nastava na daljinu, CARNET) odnosno kao »opći sustav poučavanja u kojem prevladavaju telekomunikacija i apersonalna odgojna komunikacija« (Matijević et al., 2016, 345). Apersonalna je komunikacija pritom »svaka komunikacija koja se odvija uz apersonalne medije, kao što je televizijska komunikacija, telefonska, kompjutorska i sl.« (Matijević, Radovanović, 2011, 371). Stavljajući u prvi plan udaljenost subjekata u nastavi i primjenu tehnologije, nastava na daljinu u literaturi se često poistovjećuje s mrežnom (online) nastavom te s mrežnim (online) i e-učenjem, pa i s učenjem na daljinu, ${ }^{8}$ što posljedično dovodi do nepreciznosti u uporabi navedenih naziva. Nastava na daljinu međutim širi je pojam od mrežne nastave jer uključuje i televizijsku nastavu, koja se također izvodi na daljinu. Učenje i nastava, iako povezani, zasebni su pojmovi, pa ni mrežno ni e-učenje ne bi trebalo izjednačivati s nastavom na daljinu, tim više što se oba oblika učenja mogu provoditi i u učionici, dok je upitno koliko se uopće može govoriti o učenju na daljinu. Učenje je naime psihički proces koji se »događa tamo gdje se subjekt učenja nalazi, odnosno gdje je aktivan u odnosu prema sadržaju učenja ili aktivnosti koje poučavatelj preporučuje, bez obzira na to kojim putem su mentorske ili voditeljske uloge do njega stigle« (Mati-

8 To vrijedi i za englesko govorno područje gdje se primjerice u mrežnom izdanju Britannike kao sinonimi navode distance learning, distance education, e-learning i online learning (usp. Berg, Britannica). 
jević, Topolovčan, 2017, 137), a ta se činjenica ne bi smjela previđati. Ona, slažemo se s Matijevićem, »dovodi u pitanje smislenost u novije vrijeme dosta česte sintagme učenje na daljinu« $(2017,137)$.

Za određenje pojma obrazovanja na daljinu, začetci kojega sežu u 19. stoljeće kada se razvio oblik dopisnoga školovanja, nije toliko bitna tehnologija (ona se i inače primjenjuje ukorak s vremenom), koliko je bitna uloga takva obrazovanja, njegova svrha i ciljevi. Obrazovanje na daljinu, ističe Guri-Rosenblit, namijenjeno je polaznicima koji se zbog različitih razloga nisu mogli redovito školovati $(2009,109)$, a njegova tradicionalna uloga - proširiti pristup obrazovanju i promicati društvenu jednakost u pravu na obrazovanje, bitna je i danas, osobito u zemljama u razvoju, ali i u razvijenim zemljama s obzirom na trend cjeloživotnog učenja i promjene profesionalne karijere za života te $\mathrm{s}$ obzirom na ključnu potrebu nadograđivanja stečene profesionalne izobrazbe $(2009,112)$. U skladu s navedenim držimo mogućim i poželjnim razlikovati pojmove nastava na daljinu i obrazovanje na daljinu. Prvi se pojam može odrediti s obzirom na prostornu udaljenost subjekata nastave i s obzirom na tehnološke mogućnosti, pa definicija nastave na daljinu može glasiti onako kako je navedena na mrežnim stranicama Instituta za hrvatski jezik i jezikoslovlje, da je to »nastava tijekom koje se učenici i učitelji ne nalaze $\mathrm{u}$ istome fizičkom prostoru, nego se nastava izvodi na mreži (mrežna nastava) ili televiziji (telenastava)«. Navedena definicija ujedno odgovara iskustvu koje su učenici uključeni u redoviti odgojno-obrazovni sustav i njihovi učitelji stekli i koje stječu sudjelujući u takvoj nastavi. Pojam obrazovanje na daljinu može se odrediti s obzirom na obrazovnu politiku neke zemlje koja, podržavajući dostupnost i otvorenost obrazovanja svojim građanima, različitim ustanovama omogućuje organiziranje takve vrste obrazovanja. Obrazovanje na daljinu tako je širi pojam koji uključuje i nastavu na daljinu.

\section{Uporaba razmatranih naziva}

Primjeri uporabe naziva razmatranih u ovome radu izdvojeni su postupkom pretraživanja mrežnih stranica na hrvatskome jeziku od 15 . do 31. listopada 2020. godine. Pritom su u obzir uzimani tekstovi u općejezičnome kontekstu. Primjeri su preuzimani s mreže ne zbog toga što bi tiskani tekstovi odražavali drukčiju uporabu, upravo suprotno, 
nego iz praktičnog razloga, zbog lake dostupnosti mrežnih izvora. Napominjemo da smo na odstupanja od standardnojezičnih norma upozorile samo u nekim izdvojenim primjerima.

Nazivi e-učenje (primjer 1 i 2) i e-poučavanje (primjer 3 i 4) u uporabi uglavnom odgovaraju pojmu kojemu su pridruženi (naše isticanje naziva u svim navedenim primjerima, op. a.):

(1) U potrazi ste za pouzdanim partnerom koji će vam olakšati proces digitalne transformacije edukacije? Ili vas uvesti u svijet e-učenja? Opustite se, na pravom ste mjestu.

(2) Iako je e-učenje (elektroničko učenje) u inozemstvu postalo gotovo uobičajeno, kod nas još uvijek nije u punom zamahu.

(3) Posebni ciljevi su ojačati kapacitete nastavnika u strukovnoj školi za primjenu modernih, na učenike usmjerenih pristupa u poučavanju, korištenjem suvremenih tehnologija (e-poučavanje), dostupnije i fleksibilnije stjecanje znanja i vještina učenicima strukovne škole, poboljšati uvjete za učenje i poučavanje.

(4) Treba pronaći sklad, mjeru između klasično-tradicionalnog i suvremenog e-poučavanja.

Osim hrvatskoga naziva e-učenje, koji je proširen i usvojen, povremeno se rabi i engleski naziv e-learning, koji se usuprot pravopisnoj normi redovito ne piše kosim slovima. Time se potvrđuje zapažanje da domaći naziv čak i kad se usvoji, ne istisne potpuno strani naziv, »nego se s njime usporedno upotrebljava« (Hudeček, Mihaljević, 2009, 61). Katkada se u istome tekstu nailazi i na usporednu uporabu obaju naziva, što je potaknuto pogrješnom predodžbom da se na takav način izbjegava ponavljanje:

(5) Što je e-learning i koje su ključne prednosti e-učenja? (...) Ako bi izbjegavali šire definicije e-learninga ili e-učenja, mogli bi reći kako je to zapravo dostupnija nadogradnja znanja putem računalnih tehnologija, ali po znatno nižim cijenama od standardnih metoda učenja.

U uporabi su pronađene i potvrde izjednačivanja pojma 'online učenje', pri čem se engleska sastavnica naziva također redovito ne piše kosim slovima, sa širim pojmom e-učenje:

(6) Prednosti online učenja (podnaslov, op. a.) Prednosti e-učenja su brojne. (u tekstu članka, op. a.),

dok se mobilno učenje ili m-učenje javlja kao inačica $e$-učenja, a što je u skladu s određenjem navedenih pojmova: 
(7) Od svog nastanka u kasnim 1990-ima e-učenje je bilo rastući segment obrazovanja te se očekuje još veći porast u godinama koje dolaze i to ponajviše zbog njegove novije inačice, mobilnog učenja ili m-učenja. Osim što je uvelo potpuni preokret u procesu učenja i tako društvu pružilo višestruke pogodnosti, e-učenje je također živo i rastuće tržište za koje se očekuje da će doseći zaradu od 107 milijardi \$ tijekom 2015.

U pogledu učestalosti uporabe istoznačnih naziva 'online učenje' i mrežno učenje zamjetno je da engleski naziv izrazito prevladava, no ipak, iako malobrojni, potvrđeni su i primjeri uporabe hrvatske istovrijednice:

(8) Udemy je globalno tržište za mrežno učenje i poučavanje gdje više od 13 milijuna učenika i studenata uči nove vještine te postiže svoje ciljeve zahvaljujući kolekciji od 40 tisuća tečajeva koje pružaju vrhunski stručnjaci.

(9) Kako se coronavirus COVID-19 i dalje širi, škole širom svijeta prelaze na mrežno učenje u nastojanju da (se) uspori širenje bolesti.

Četiri se naziva, e-nastava, online nastava, mrežna nastava i virtualna nastava, pretežito rabe kao istoznačnice (primjeri 10-17), pa čine sinonimni niz, iako su prave istoznačnice samo nazivi 'online nastava' i mrežna nastava, koji čine sinonimni par:

(10) Molimo studente da za e-nastavu obavezno koriste FFST domenu, odnosno e-mail adrese koje su dobili na fakultetu.

(11) Nastavno na novonastalu situaciju vezanu uz COVID-19, Zdravstveno veleučilište je osiguralo informacijske resurse za održavanje e-nastave i komunikaciju sa studentima.

(12) Dobro došli na portal za online nastavu Fakulteta organizacije i informatike!

(13) Na području Zagrebačke županije od ovoga tjedna kreće online nastava

(14) OSNOVNA ŠKOLA IVANEC Prelazak na mrežnu nastavu: Virtualne učionice za učenike viših razreda spremne za početak rada

(15) S obzirom na situaciju u kakvoj se nalazimo danas, ali ćemo se i još neko vrijeme, mrežna nastava praktična je preventiva od općeg kaosa školske 2019./2020. godine.

(16) ASOO virtualna nastava za strukovne škole

(17) Iako virtualna nastava još uvijek nije započela, većina nastavnika naveliko se priprema za nju. 
Kao izolirani primjer naziva koji se uklapa u sinonimni niz e-nastava, online nastava, mrežna nastava i virtualna nastava, potvrđen je i naziv internet nastava:

(18) Već duže vrijeme u Gaudeamusu se provodi Internet nastava.

koji bi, usklađen s tvorbenom i s pravopisnom normom hrvatskoga standardnoga jezika, trebao glasiti internetska nastava. Navedene nazive poželjno bi bilo rabiti ovisno o tome što se zapravo pod njima razumijeva. S obzirom na to da je e-nastava opsegom širi pojam od mrežne (online) nastave, ona naime uključuje i mješovitu i mrežnu nastavu, opravdano je na mrežnoj stranici koja pruža obavijest o provedbi upravo takve nastave upotrebljavati naziv e-nastava (primjer 10 i 11). Kad je posrijedi izbor između engleskoga i hrvatskoga parnjaka 'online' odnosno mrežna nastava, sudionici mrežne komunikacije češće se odlučuju za englesku inačicu, koja se piše ili kao jedna riječ, češće, ili kao polusloženica (on-line), rjeđe. S druge strane, potvrđen je i primjer uporabe naziva virtualna nastava koji je motiviran razlikom između realnoga i virtualnog svijeta, pa taj naziv s obzirom na surječje ne bi bio zamjenjiv primjerice nazivom mrežna nastava bez gubitka iznijansirane značenjske razlike:

(19) Praksa pokazuje: virtualna nastava nije adekvatna zamjena nastavi uživo

Činjenica je da postoje dva svijeta - realni svijet i virtualni svijet. Većina ljudi obitava u oba svijeta paralelno, dok manjina (uglavnom starije populacije) prebiva isključivo u realnom svijetu. Još manji, ali nažalost rapidno rastući, broj ljudi živi isključivo u virtualnomu svijetu ili za njega. Takvomu stanju duha uvelike su doprinijele razne društvene mreže, poput Facebooka, Tweetera i Instagrama. Čak postoji i šala koja kaže: »Ako nije na Facebooku, nije se ni dogodilo.«

Također se nailazi na usporednu uporabu dvaju istoznačnih naziva u istome tekstu, 'on-line nastava' i mrežna nastava, što je, kao i kod usporedne uporabe naziva e-učenje i 'e-learning', potaknuto nastojanjem da se izbjegne ponavljanje:

(20) On-line nastava na Akademiji za umjetnost i kulturu u Osijeku U roku tri dana, do 15. ožujka formirani su rasporedi za mrežnu nastavu, objavljeni na mrežnim stranicama, poslani nastavnicima i studentima te u Ministarstvo. U mrežnoj nastavi Akademije koriste se sve, od nastavnika 
predložene i dostupne, platforme i komunikacijski kanali (Merlin, Loomen, Google učionice, Teams, Zoom, WhatsApp, Skype i dr.). (...) Svi studenti, redoviti i izvanredni, preddiplomskih, diplomskih i poslijediplomskih studija, uključeni su u mrežnu nastavu.

odnosno neistoznačni nazivi e-nastava i 'online nastava' rabe se kao istoznačni:

(21) Capaka pitali hoće li se otvoriti fakulteti: 'E-nastava ide dobro, nema prepreke da se završi online' Na današnjoj press konferenciji Stožera civilne zaštite Krunoslav Capak, ravnatelj HZJZ-a ponovno se dotakao online nastave.

Dodatno, navedenome nizu u uporabi istoznačnih naziva pridružuju se i nazivi učenje i poučavanje na daljinu, nastava na daljinu, škola na daljinu, a javlja se i naziv virtualno učenje:

(22) Potrebno je u školama učiniti potrebne tehničke pripreme kako bi učenicima i nastavnicima u slučaju potrebe osigurali učenje i poučavanje na daljinu (online nastava) (...).

(23) Počela škola na daljinu: donosimo raspored online nastave

Od ponedjeljka, 16. ožujka 2020., zbog epidemije koronavirusa u Hrvatskoj je prekinuta redovita, a pokrenuta online nastava. Virtualne učionice prvo su otvorene u Istarskoj županiji, a od srijede se virtualna nastava održava i u ostatku Hrvatske. No, u školu na daljinu su uključene i televizije (...).

(24) Učenici nam otkrili kako funkcionira online nastava (naslov vijesti, op. a.) Šestero učenika otkrilo nam je kako u njihovim školama funkcionira nastava na daljinu. (u tekstu vijesti, op. a.)

(25) Nastava se može provoditi u obliku nastave na daljinu (virtualna nastava), korištenjem sredstava elektroničke komunikacije.

(26) UNICEF ulaže u dugoročno unaprjeđenje mrežne nastave u Hrvatskoj (naslov vijesti, op. a.)

Gotovo pola milijuna kuna vrijedno ulaganje u unaprjeđenje kvalitete nastave na daljinu (u tekstu vijesti, op. a.).

(27) Uživo online nastava na daljinu - Škola za život 18.03.2020 (srijeda) S obzirom na novonastalu situaciju oko korona virusa, početkom ovog tjedna počela je online škola na daljinu.

(28) OPET ONLINE NASTAVA? Ako opasnost od drugog vala bude umjerena, kombinacija online i nastave u učionicama Tri su moguća scenarija prema kojima može početi nova nastavna godina 2020./2021.: nastavom pretežito uživo u školskim učionicama, prema mješovitom modelu ili pretežito na daljinu. (...) U tom modelu (kombinacija nastave uživo i nastave na daljinu) u nas ove školske godine sudjeluju uglavnom učenici od prvog do četvrtog razreda osnovne škole koji su nastavu najprije pratili na televiziji 
(HRT 3) te u komunikaciji roditelja i učitelja putem grupa na WhatsAppu, Viberu i slično, da bi se od svibnja većina njih vratila u školske učionice, a dio ostao u nastavi na daljinu.

(29) Uvođenjem nastave na daljinu Opća privatna gimnazija prepoznala je priliku kako biti što učinkovitiji te se odmah krenulo s organizacijom edukacije za nastavnike o korištenju edmodo, zoom i skype platformi. Cilj je bio osposobiti nastavnike za rad u virtualnom okruženju.

Veliki naglasak stavljen je na realno vrijeme održavanja virtualne nastave. Online nastava nije samo postavljanje materijala, slanje poruka u virtualne učionice, gdje učenici u neko doba dana rješavaju zadatke, pa pri tome nailaze na bezbroj pitanja, a nemaju koga pitati. Virtualno učenje nije jednostrana komunikacija, ono funkcionira na konstruktivan način, u realnom vremenu prema rasporedu sati, učenici se uključuju putem kamera te uz postavljene prezentacije i zadatke sudjeluju u kreiranju nastave.

$\mathrm{U}$ navedenim se primjerima kao istoznačnice rabe nazivi učenje i poučavanje na daljinu i 'online nastava' (primjer 22), 'online nastava', virtualna nastava i škola na daljinu (primjer 23), 'online nastava' i nastava na daljinu (primjer 24 i 28), nastava na daljinu i virtualna nastava (primjer 25), mrežna nastava i nastava na daljinu (primjer 26), 'online nastava na daljinu' i 'online škola na daljinu' (primjer 27), virtualna nastava, 'online nastava' i nastava na daljinu (primjer 29), a rabi se i sintagma virtualno učenje (primjer 29), što pridonosi dojmu o neuređenosti nazivlja koje se odnosi na e-izvedbu nastave. Nastava na daljinu, podsjećamo, uključuje mrežnu i televizijsku nastavu, dakle širi je pojam od mrežne ('online') i virtualne nastave, pa taj naziv ne bi bilo preporučljivo rabiti kao istoznačnicu mrežnoj i virtualnoj nastavi. $\mathrm{S}$ druge strane, opravdana bi bila uporaba sintagme online nastava na daljinu u primjeru 27 (preporuka: mrežna nastava na daljinu) jer naziv online pobliže određuje vrstu takve nastave. Izjednačivanje nastave na daljinu sa školom na daljinu nije uputno zbog toga što je nastava samo jedan vid školske djelatnosti. Za sintagmu poučavanje na daljinu, slažemo se s Matijevićem, može se naći razlog za uporabu (Matijević, Topolovčan, 2017, 137), ali o učenju na daljinu, kako smo prethodno obrazložili, nije opravdano govoriti jer se učenje događa u subjektu učenja i to 'sada i ovdje' - u vremenu kada uči i na mjestu na kojem uči. Može se reći da to isto vrijedi i za sintagmu virtualno učenje. Odrednica 'uživo' povezuje se pak ne samo s nastavom u učionici (primjer 28) nego i s 'online nastavom' (primjer 27), a što je, kako smo naveli, opravdano s obzirom na mogućnosti koje pruža mrežna nastava. 


\section{Zaključak}

Pregledom literature na hrvatskome i engleskome jeziku utvrđeno je da pojedini hrvatski autori pod utjecajem literature na engleskome jeziku pod pojmom e-učenja razumijevaju i e-poučavanje, što nije u skladu s razlikom između učenja i poučavanja uspostavljenom u pedagogijskoj znanosti. U literaturi se nailazi i na poistovjećivanje pojmova nastava na daljinu, obrazovanje na daljinu, mrežna (online) nastava, mrežno (online) i e-učenje te učenje na daljinu.

Analiza literature usredotočena na definiranje sedam promatranih i drugih njima srodnih naziva pokazala je sljedeće:

- opsegom su širi pojmovi e-učenje od mrežnog (online) učenja; e-nastava od mrežne (online, internetske) nastave; e-obrazovanje od e-nastave; nastava na daljinu od mrežne nastave; obrazovanje na daljinu od nastave na daljinu

- odnos istoznačnosti može se uspostaviti između naziva e-učenje i 'e-learning'; 'online učenje' i mrežno učenje; 'online nastava', mrežna nastava i internetska nastava

- odnos bliskoznačnosti može se uspostaviti između naziva mrežna (online, internetska) i virtualna nastava

- nazivi učenje na daljinu i virtualno učenje nemaju uporišta u pedagogijskoj znanosti

- opis nastava 'licem u lice' i nastava 'uživo' može se odnositi i na nastavu u učionici i na mrežnu nastavu.

Razlike među autorima u definiranju razmatranih naziva odražavaju se i na uporabu, no broj pojmova koji se poistovjećuju u uporabi još je i veći. Poistovjećuju se pojmovi e-nastava, mrežna (online, internetska (internet)) nastava, virtualna nastava, nastava na daljinu i škola na daljinu te učenje i poučavanje na daljinu. U pogledu uporabe također je utvrđeno:

- nazivi e-učenje i e-poučavanje uglavnom odgovaraju pojmu kojemu su pridruženi, no potvrđeno je i izjednačivanje pojma 'online učenje' sa širim pojmom e-učenje

- naziv mobilno učenje ili m-učenje rabi se kao inačica e-učenja

- češće se potvrđuje naziv e-učenje od naziva e-learning, dok je engleska sastavnica online u nazivima 'online učenje' i 'online na- 
stava' znatno raširenija od hrvatskih istovrijednica mrežno učenje i mrě̌na nastava

- engleski se naziv i engleske sastavnice u nazivu redovito ne pišu kosim slovima

- raširena je pojava usporedne uporabe istoznačnih naziva u istome tekstu i uporabe neistoznačnih naziva kao istoznačnih, također u istome tekstu.

Navedeni zaključci upućuju na potrebu preciznijeg definiranja i usustavljivanja nazivlja za e-izvedbu nastave. Prilog je tomu i ovaj rad.

\section{Literatura}

Antić, Stanko (1999), »Pedagoški pojmovnik«, u: Mijatović, Antun (ur.), Osnove suvremene pedagogije, Zagreb: Hrvatski pedagoško-književni zbor, str. 641-655.

Bates, Tony (2008), »What is e-learning?«, Tony Bates website by Contact North. Dostupno na: https://www.tonybates.ca/2008/07/07/what-is-e-learning/ [5. 9. 2020.]

Berg, Gary A. »Distance learning«, Britannica, mrežno izdanje. Dostupno na: https://www.britannica.com/topic/distance-learning [5. 9. 2020.]

Bežen, Ante (2008), Metodika - znanost o poučavanju nastavnog predmeta. Epistemologija metodike u odnosu na pedagogiju i edukologiju - s primjerima iz metodike hrvatskoga jezika, Zagreb: Učiteljski fakultet - Profil.

Bolje je hrvatski. Dostupno na: https://bolje.hr/rijec/on-line-gt-mrezni-internet$\underline{\text { ski/208/ [7. 9. 2020.] }}$

Bozkurt, Aras (2019), »From distance education to open and distance learning: A holistic evaluation of history, definitions, and theories«, u: Sisman-Ugur, Serap; Kurubacak, Gulsun (ur.), Handbook of Research on Learning in the Age of Transhumanism, Hershey, PA: IGI Global, str. 252-273. Dostupno na: https://www.igi-global.com/book/handbook-research-learning-age-transhumanism/217946 [28. 8. 2020.]

Bratanić, Marija (2002), Paradoks odgoja: studije i eseji, Zagreb: Hrvatska sveučilišna naklada.

[CARNet] Hrvatska akademska i istraživačka mreža, Nastava na daljinu, Hrvatska akademska i istraživačka mreža. Dostupno na: https://www.carnet.hr/usluga/ udaljenoucenje/ [28. 8. 2020.]

[CARNet] Hrvatska akademska i istraživačka mreža, Što je online učenje?, Hrvatska akademska i istraživačka mreža. Dostupno na: https://loomen.carnet.hr/ mod/book/view.php?id=413809 [28. 8. 2020.]

[COM] Commission of the European Communities (2001), Communication from the Commission: Making a European Area of Lifelong Learning a 
Reality, Brussels: Commission of the European Communities. Dostupno na: https://www.europarl.europa.eu/meetdocs/committees/cult/20020122/ com(2001)678 en.pdf [5. 9. 2020.]

E-učenje. Wikipedija, 2020. Dostupno na: https://hr.wikipedia.org/wiki/E-učenje [28. 8. 2020.]

Giesecke, Hermann (1993), Uvod u pedagogiju, Zagreb: Educa.

Guri-Rosenblit, Sarah (2009), »Distance Education in the Digital Age: Common Misconceptions and Challenging Tasks«, Journal of Distance Education, 23(2), str. 105-122. Dostupno na: https://www.researchgate.net/publication/234627278 Distance Education in the Digital Age Common Misconceptions and Challenging Tasks [12.9. 2020.]

Hrvatski pravopis (2013), Jozić, Željko (ur.), Zagreb: Institut za hrvatski jezik i jezikoslovlje.

Hrvatski terminološki portal Instituta za hrvatski jezik i jezikoslovlje (2020), Što je nazivlje?, Hrvatski terminološki portal Instituta za hrvatski jezik i jezikoslovlje. Dostupno na: https://nazivlje.hr/clanak/sto-je-nazivlje/14/ [29. 8. 2020.]

Hudeček, Lana; Mihaljević, Milica (u suradnji s Brunom Nahodom) (2009), Hrvatski terminološki priručnik, Zagreb: Institut za hrvatski jezik i jezikoslovlje.

Institut za hrvatski jezik i jezikoslovlje, Nastava na daljinu, Institut za hrvatski jezik i jezikoslovlje. Dostupno na: https://jezik.hr/koronavirus/pretraga/?search=telenastava [29. 8. 2020.]

Jandrić, Petar; Boras, Damir (2012), Kritičko e-obrazovanje: borba za moć i značenje u umreženom društvu, Zagreb: Tehničko veleučilište u Zagrebu - Filozofski fakultet Sveučilišta u Zagrebu FF Press.

Jandrić, Petar, Tomić, Vesna; Kralj, Lidija (2016), E-učitelj - suvremena nastava uz pomoć tehnologije, Zagreb: Hrvatska akademska i istraživačka mreža CARNet. Dostupno na: https://pilot.e-skole.hr/wp-content/uploads/2016/12/ Prirucnik_e-Ucitelj.pdf [12. 9. 2020.]

Jelavić, Filip (1991), »Obrazovanje i odgoj«, u: Bežen, Ante; Jelavić, Filip; Kujundžić, Nedjeljko; Pletenac, Vladimir, Osnove didaktike, Zagreb: Školske novine.

Jelavić, Filip (1998), Didaktika, Jastrebarsko: Naklada Slap.

King, Frederick B., Young, Michael F., Drivere-Richmond, Kelly; Schrader, P. G. (2001), »Defining distance learning and distance education«, AACE Journal, 9(1), str. 1-14. Norfolk, VA: Association for the Advancement of Computing in Education (AACE). Dostupno na: https://www.learntechlib.org/pri$\underline{\operatorname{mary} / \mathrm{p} / 17786 / \text { [12.9. 2020.] }}$

Kiš, Miroslav (2000), Englesko-hrvatski, hrvatsko-engleski informatički rječnik, Zagreb: Naklada Ljevak.

Krtanjek, Đurđica, 2020, »Nastava na daljinu - Stvarnost, a ne mit«, Školski portal. Dostupno na: https://www.skolskiportal.hr/uncategorized/stvarnost-ane-mit/ [3. 9. 2020.] 
Matijević, Milan; Bilić, Vesna; Opić, Siniša (2016), Pedagogija za učitelje i nastavnike, Zagreb: Školska knjiga.

Matijević, Milan; Radovanović, Diana (2011), Nastava usmjerena na učenika. Prinosi razvoju metodika nastavnih predmeta u srednjim školama, Zagreb: Školske novine. Dostupno na: http://milan-matijevic.com/wp-content/uploads/2010/05/Nastava-usmjerena-na-učenike-2011-finalno-knjiga1.pdf [12. 9. 2020.]

Matijević, Milan; Topolovčan, Tomislav (2017), Multimedijska didaktika, Zagreb: Školska knjiga.

Meyer, Hilbert (2002), Didaktika razredne kvake: rasprave o didaktici, metodici $i$ razvoju škole, Zagreb: Educa.

Milat, Josip (2005), Pedagogija - teorija osposobljavanja, Zagreb: Školska knjiga.

Panian, Željko (2005), Englesko-hrvatski informatički enciklopedijski rječnik (M$Z)$, Zagreb: Europapress holding.

Peko, Anđelka; Pintarić, Ana (1999), Uvod u didaktiku hrvatskoga jezika, Osijek: Pedagoški fakultet.

Peko, Anđelka (2007), »Učiti kako poučavati«, u: Previšić, Vlatko; Šoljan, Nikša Nikola; Hrvatić, Neven (ur.), Pedagogija prema cjeloživotnom obrazovanju i društvu znanja, svezak 1, Zagreb: Hrvatsko pedagogijsko društvo, str. 260-274.

Pop, Alexandru (2020), »What's the Difference Between Blended Learning, E-Learning and Online Learning?« (15. 10. 2020.). Dostupno na: https://www. distancelearningportal.com/articles/269/whats-the-difference-between-blended-learning-e-learning-and-online-learning.html [20. 10. 2020.]

Pogarčić, Ivan; Babić, Snježana; Vukelić, Bernard (2007), »E ili M: U čemu je razlika?«, u: Polonijo, Mislav (ur.), CASE 19 - Metode $i$ alati za razvoj poslovnih i informacijskih sustava, Rijeka: CASE d. o. o. Dostupno na: https:// www.bib.irb.hr/329430 [13. 11. 2020.]

Pranjković, Ivo (2010), Ogledi o jezičnoj pravilnosti, Zagreb: Disput.

Previšić, Vlatko (2003), »Suvremeni učitelj: odgojitelj - medijator - socijalni integrator«, u: Ličina, Berislav (ur.), Učitelj - učenik - škola, Zbornik radova Drugoga međunarodnoga znanstvenog kolokvija. Rijeka: Filozofski fakultet, str. 78-84.

Radeka, Igor (2007), »Uloga nastavnika u cjeloživotnom obrazovanju«, Pedagogijska istraživanja, 4(2), str. 283-291.

Rječnik hrvatskoga jezika (2000), Šonje, Jure (ur.), Zagreb: Leksikografski zavod Miroslav Krleža - Školska knjiga.

Saykili, Abdullah (2018), »Distance education: Definitions, generations, key concepts and future directions«, International Journal of Contemporary Educational Research, 5(1), str. 2-17. Dostupno na: https://www.researchgate. net/publication/338825629_Distance_Education_Definitions_Generations Key_Concepts_and_Future_Directions [9.9.2020.] 
[SRCE] Sveučilišni računski centar Sveučilišta u Zagrebu, E-učenje, Sveučilišni računski centar Sveučilišta u Zagrebu. Dostupno na: https://www.srce.unizg. hr/usluge/centar-za-e-ucenje/o-centru/e-ucenje [29. 8. 2020.]

Sveučilište u Zagrebu (2007), Strategija e-učenja 2007. - 2010., Zagreb: Sveučilište u Zagrebu. Dostupno na: http://www.unizg.hr/fileadmin/rektorat/Studiji studiranje/Studiji/e-ucenje/e-ucenje_strategija/Sveuciliste u Zagrebu_Strategija e ucenja Senat v1.pdf [5. 9. 2020.]

Težak, Stjepko (1996), Teorija i praksa nastave hrvatskoga jezika 1, Zagreb: Školska knjiga.

virtualan. Hrvatska enciklopedija, mrežno izdanje, Leksikografski zavod Miroslav Krleža, 2020. Dostupno na: http://www.enciklopedija.hr/Natuknica. aspx? ID $=64792$ [20.9. 2020.]

Visinko, Karol (2010), Jezično izražavanje u nastavi hrvatskoga jezika: pisanje, Zagreb: Školska knjiga.

\section{Primjeri s mrežnih izvora}

(1) »Programi za e-učenje«, HalPet. Dostupno na: https://halpet.hr/programi-za-e-ucenje/ [31. 10. 2020.]

(2) »Najbolje stranice za e-učenje«, mrežne stranice Veleučilišta Velika Gorica. Dostupno na: https://vvg.hr/ict/is/najbolje-stranice-za-e-ucenje [31. 10. 2020.]

(3) »Uvođenje e-učenja u svrhu poboljšanja nastavnih procesa u strukovnim programima u Srednjoj školi Marka Marulića Slatina i Srednjoj školi Isidora Kršnjavoga Našice«, Europski strukturni i investicijski fondovi. Dostupno na: http://arhiva.strukturnifondovi.hr/projekti?projekt id=20 [31. 10. 2020.]

(4) Kaznačić, Mirjana (2018), »Mirjana Kaznačić, ravnateljica OŠ Lapad - Kamo ide poučavanje«, Glas Grada, 30. 3. 2018. Dostupno na: https://www.glasgrada.hr/mirjana-kaznacic-ravnateljica-o-s-lapad-kamo-ide-poucavanje $\left[\begin{array}{ll}15 . & 10 .\end{array}\right.$ 2020.]

(5) »Što je e-learning i koje su ključne prednosti e-učenja?«, Digitalna agencija Marke Thing d.o.o., 29. 3. 2020. Dostupno na: https://www.markething.hr/e-learning-kljucne-prednosti/ [31. 10. 2020.]

(6) »Što je online učenje, e-učenje i učenje na daljinu?«, Finnix Education for All. Dostupno na: http://e-nauci.me/corporate/index.php/naslovnica/8-novosti-i-dogadanja/24-sto-je-online-ucenje-e-ucenje-i-ucenje-na-daljinu [31. 10. 2020.]

(7) Matović, Miloš, »Lokalizacija e-učenja i m-učenja: prevođenje znanja«, Ciklopea. Dostupno na: https://ciklopea.com/hr/blog-hr/lokalizacija/lokalizacija-e-ucenja-i-m-ucenja-prevodenje-znanja/ [15. 10. 2020.]

(8) »Besplatni mrežni tečajevi«, Školski portal Školske knjige, 27. 8. 2020. Dostupno na: https://www.skolskiportal.hr/sadrzaj/iz-stranih-medija/besplatni-mrezni-tecajevi/ [31. 10. 2020.] 
(9) Snelling, Jennifer; Fingal, Diana (2020), »10 strategija za mrežno učenje tijekom epidemije coronavirusa«, ISTE blog, 16. 3. 2020. Dostupno na: https:// www.iste.org/hr/explore/learning-during-covid-19/10-strategies-online-learning-during-coronavirus-outbreak [31. 10.2020.]

(10) Pisac Šumić, Ivana (2020), »E-nastava - upute«, mrežne stranice Filozofskog fakulteta u Splitu, 17. 3. 2020. Dostupno na: https://www.ffst.unist.hr/e-nastava-upute/ [31. 10.2020.]

(11) »Upute studentima za sudjelovanje u procesima e-nastave i komunikaciji s nastavnicima Zdravstvenog veleučilišta«, mrežne stranice Zdravstvenog veleučilišta Zagreb, 14. 3. 2020. Dostupno na: https://www.zvu.hr/upute-studentima-za-sudjelovanje-u-procesima-e-nastave-i-komunikaciji-s-nastavnicima-zdravstvenog-veleucilista/ [31. 10. 2020.]

(12) »FOI online nastava«, mrežne stranice Fakulteta organizacije i informatike Varaždin Sveučilišta u Zagrebu. Dostupno na: https://www.foi.unizg.hr/hr/ online-nastava [31. 10. 2020.]

(13) »Od idućeg tjedna: Na području Zagrebačke županije u srednjim školama kreće online nastava«, Večernji list (Hina), 27. 11. 2020. Dostupno na: https:// www.vecernji.hr/vijesti/pala-odluka-od-iduceg-tjedna-u-srednjim-skolama-krece-online-nastava-1449532 [31. 10. 2020.]

(14) »Osnovna škola Ivanec Prelazak na mrežnu nastavu: Virtualne učionice za učenike viših razreda spremne za početak rada«, Ivanec News Portal, 18. 3. 2020. Dostupno na: https://www.eivanec.com/osnovna-skola-ivanec-prelazak-na-mreznu-nastavu-virtualne-ucionice-za-ucenike-visih-razreda-spremne-za-pocetak-rada/ [31. 10. 2020.]

(15) Novak, Lorena (2020), »Školski (ne)sustav osnovnih škola 21. stoljeća«, Pressedan.hr, eksperimentalni portal studenata Sveučilišta Sjever, 29. 3. 2020. Dostupno na: http://pressedan.unin.hr/skolski-nesustav-osnovnih-skola-21-stoljeca.html [31. 10. 2020.]

(16) »ASOO virtualna nastava za strukovne škole«, mrežne stranice Agencije za strukovno obrazovanje i obrazovanje odraslih. Dostupno na: https://nastava. asoo.hr/ [31. 10. 2020.]

(17) Gelenčir, Martina (2020), „Virtualna nastava još nije započela, a nastavnici već imaju poteškoća s prijavom u sustav«, Srednja.hr, 14. 3. 2020. Dostupno na: https://www.srednja.hr/novosti/virtualna-nastava-jos-nije-zapocela-a-nastavnici-vec-imaju-poteskoca-s-prijavom-sustav/ [31. 10. 2020.]

(18) »Internet nastava«, mrežne stranice Gimnazije Gaudeamus. Dostupno na: https://www.gaudeamus.hr/gaudeamus/upisi/internet-nastava/ [31. 10. 2020.]

(19) »Praksa pokazuje: virtualna nastava nije adekvatna zamjena nastavi uživo«, Siscia.hr, sisački informativni portal, 29. 4. 2020. Dostupno na: https://siscia. hr/virtualna-nastava/ [31. 10. 2020.]

(20) Pacek, Jasmina (2020), »On-line nastava na Akademiji za umjetnost i kulturu u Osijeku«, Glas Slavonije, 25. 4. 2020. Dostupno na: https://www.glas-slavonije.hr/430948/25/On-line-nastava-na-Akademiji-za-umjetnost-i-kulturu-u-Osijeku [31. 10.2020.] 
(21) Gaščić, Denis (2020), »Capaka pitali hoće li se otvoriti fakulteti: 'E-nastava ide dobro, nema prepreke da se završi online «, Srednja.hr, 21. 4. 2020. Dostupno na: https://www.srednja.hr/novosti/capaka-pitali-hoce-li-se-otvoriti-fakulteti-e-nastava-ide-dobro-nema-prepreke-da-se-zavrsi-online/ [31. 10. 2020.]

(22) »Od ponedjeljka online nastava«, Dugi Rat Online, 12. 3. 2020. Dostupno na: https://www.dugirat.com/novosti/100-obrazovanje/27973-online-nastava-ako-koronavirus-zatvori-sve-skole [31. 10. 2020.]

(23) »Počela škola na daljinu: donosimo raspored online nastave«, mrežne stranice Agencije za mobilnost i programe EU, 16. 3. 2020. https://www.mobilnost.hr/ $\underline{\mathrm{hr} / \text { novosti/pocela-skola-na-daljinu-donosimo-raspored-online-nastave/ }}[31$. 10. 2020.]

(24) Gelenčir, Martina (2020), „Učenici nam otkrili kako funkcionira online nastava: 'Čitava situacija je jedna velika katastrofa' «, Srednja.hr, 17. 3. 2020. Dostupno na: https://www.srednja.hr/zbornica/ucenici-nam-otkrili-funkcionira-online-nastava-citava-situacija-jedna-velika-katastrofa/ [31. 10. 2020.]

(25) »Nastava u kući i zdravstvenoj ustanovi«, Središnji državni portal. Dostupno na: https://gov.hr/moja-uprava/obrazovanje/osnovnoskolski-odgoj-i-obrazovanje/nastava-u-kuci-i-zdravstvenoj-ustanovi/223 [31. 10. 2020.]

(26) »UNICEF ulaže u dugoročno unaprjeđenje mrežne nastave u Hrvatskoj«, UNICEF Hrvatska, 2. 6. 2020. Dostupno na: https://www.unicef.org/croatia/ mediji/unicef-ulaze-u-dugorocno-unaprjedenje-mrezne-nastave-u-hrvatskoj [31. 10. 2020.]

(27) Komarić, Božidar (2020), »Uživo online nastava na daljinu - Škola za život 18. 03. 2020 (srijeda)«, Računalo.com, 18. 3. 2020. https://www.racunalo. com/uzivo-online-nastava-na-daljinu-skola-za-zivot-18-03-2020-srijeda-korona-virus/ [31. 10. 2020.]

(28) Cvrtila, Marijana (2020), »Opet online nastava?«, Jutarnji list, 10. 6. 2020. Dostupno na: https://www.jutarnji.hr/vijesti/hrvatska/opet-online-nastava-ovo-su-tri-modela-za-novu-skolsku-godinu-koji-ce-od-tih-scenarija-prevagnuti-ovisit-ce-o-epidemioloskoj-situaciji-10389715 [31. 10. 2020.]

(29) »Zavirili smo u online nastavu Opće privatne gimnazije koja je ukorak sa svjetskim trendovima«, Živim.hr, 30. 4. 2020. https://zivim.gloria.hr/zivim/ rastem/zavirili-smo-u-online-nastavu-opce-privatne-gimnazije-koja-je-u-korak-sa-svjetskim-trendovima-10261174 [31. 10. 2020.] 


\title{
DEFINING AND USING TERMS FOR E-TEACHING MODALITIES
}

\author{
Jadranka Nemeth-Jajić, Tonća Jukić
}

Due to a pandemic caused by a coronavirus, teaching in Croatian schools in the second half of the school year 2019/2020 and at Croatian universities in the summer semester of the same academic year took place online. It has introduced various synonymous, paronymous or insufficiently precise terms into the public and professional discourse, which motivates us to re-examine their meaning and the scope of the concept to which they refer. This paper focuses on defining seven selected terms, aiming to contribute to a more precise usage of e-teaching terminology. Furthermore, after searching web pages in the Croatian language by keywords, we single out examples of their use. These are the following terms: e-learning, e-teaching, e-classes, web-based teaching, online teaching, virtual teaching and distance education.

Keywords: e-learning, e-teaching, e-classes, web based teaching, online teaching, virtual teaching, distance education 